Margono, F.P., \& Gantino, R. (2021). The Influence of Firm Size, Leverage, Profitability, and Dividend Policy on Firm Value of Companies in Indonesia Stock Exchange. Copernican Journal of Finance \& Accounting, 10(2), 45-61. http://dx.doi.org/10.12775/CJFA.2021.007

\author{
Ferdy Prasetya Margono* \\ Esa Unggul University \\ Rilla Gantino** \\ Esa Unggul University
}

\title{
THE INFLUENCE OF FIRM SIZE, LEVERAGE, PROFITABILITY, AND DIVIDEND POLICY ON FIRM VALUE OF COMPANIES IN INDONESIA STOCK EXCHANGE
}

Keywords: firm value, firm size, leverage, profitability, dividend policy.

\author{
J E L Classification: M41.
}

Abstract: The aim of this study is to acquire empirical proof on the impact of firm size, leverage, profitability, and dividend policy on the firm value of the consumer goods industry in the food \& beverage sub-sector listed on IDX in 2016-2019. Firm size is calculated by Ln of total sales, leverage is calculated by the Debt to Assets Ratio (DAR), profitability is calculated by Return On Equity (ROE), dividend policy is calculated by Dividend Payout Ratio (DPR), and firm value is calculated by Price to Book Value (PBV).

The methodology used purposive sampling. The number of samples used in this research were 10 consumer goods industry companies in the food and beverage sub-sector listed on the IDX during 2016-2019. The data source of this research comes from the

Date of submission: March 18, 2021; date of acceptance: May 5, 2021.

* Contact information: margonoferdyprasetyaueu@gmail.com, Economic and Business Faculty, Esa Unggul University, Indonesia, phone: +62 87850967505; ORCID ID: https://orcid.org/0000-0002-4264-8265.

** Contact information: rilla.gantino@esaunggul.ac.id, Economic and Business Faculty, Esa Unggul University, Indonesia, phone: +62 87850967505; ORCID ID: https://orcid.org/0000-0002-3626-6033. 
company's yearly financial reports. This research uses a quantitative oncoming with multiple linear regression analysis methods.

The resumes of this research found that firm size, leverage, profitability, and dividend policy simultaneously influence firm value; firm size has no impact on company value; leverage has a positive impact on company value; profitability has a positive impact on company value; and dividend policy has a positive impact on company value.

\section{INTRODUCTION}

The company as an organization that carries out product creation activities in its operations has a goal in a short time and long time. The short objective of the company is to get maximum profit by managing the available assets, on the other hand, the long time goal is to optimize the value of the enterprise (Novari \& Lestari, 2016). The firm value can be calculated, one of which is the market share price which comes from the occurrence of the market share price which is a reflection of the enterprise's ability (Harmono, 2014). Not only by referring to stock prices, firm value can be observed from the firm size which is considered capable of having an impact on enterprise value. Because, the augmentative size of the enterprise will make it establish for the corporation to get funding from inside or outside the firm (Pratama \& Wiksuana, 2016).

The firm size is considered to have an impact on the firm value for the continued increase in company value makes it easy for the company to get funding income that can be used to achieve company goals, but in other parts it can create large debts because the risk of the company in fulfilling its obligations is quite small (Indriyani, 2017). Suwardika and Mustanda (2017) said that if the company size is observed from the sum of equity, sales, or total assets. The increasing overall assets of the company can reflect that the company has reached its maturity stage. Companies that are already in an adult position show that the firm already has positive cash flow and is expected to have a long term profitable outlook.

Leverage is the level of the loan by the company to perform its operational actions. Leverage arises because the firm will carry out its operations using assets and funding income which has flat costs and can increase returns for the company (Hasibuan, 2017). Ernawati and Widyawati (2015) said that the increasing leverage proves that the risk of capital is getting bigger as well. A company with a small leverage ratio has a fairly small leverage risk. This comparison can reflect how much the firm financed by loans or outsiders with the company's expertise. Debt comes from banks and other financing institu- 
tions. Companies that get a lot of financing from debt are considered not good because they can reduce profits.

Firm value can also be affected by the measure from profitability that the firm receives. If profitability is good, the firm's authority holders consisting of suppliers, creditors, and investors want to see how long the company can create profits from marketing activities and company capital. The calculation of the level of profitability is carried out in order to see the company's performance in seeking profit. This profitability is also used to see the size of the effectiveness from organizing a firm which is shown from the gains obtained by selling or capital revenue (Mayliza \& Sari, 2018).

Company value can also be affected by the dividend policy of each company. Investors are lured to give their capital by referring to the data that is informed by the firm in the form of reports on the firm's profits and losses. This is due to the aim of the investors to obtain a good level of welfare by getting a return on the funds they have invested. Investors are lured into making investments based on the dividend policy made by the company. A company's dividend policy is quite a complicated matter because it has to link the many needs of the parties involved in the company. Dividend policy can be defined as how much income can be paid as dividends and how much can be maintained (Ayem \& Nugroho, 2016).

This research was conducted because of the incompatibility phenomenon between the theoretics and the results of prior study. For example, firm size which theoretically has a positive impact on firm value, yet Hirdinis' research resumes (2019) state the company size has a negative impact on firm value; leverage in the theory has a negative impact on firm value, but Markonah's research results (2020) state that leverage has a positive impact on company value; profitability in the theory has a positive impact on company value, however the results of Pratama's and Wiksuana's research (2016) state that profitability has a negative impact on firm value; dividend policy which in the theory has a positive impact on company value, but the results of Husna's and Satria's research (2019) show that dividend policy has no impact on firm value.

The objective from the research is to investigate the impact of firm size, leverage, profitability, and dividend policy on firm value in food \& beverage companies listed on IDX in 2016-2019. The outcome of this research are intended to be used as data by the company for management in establish policies to increase the welfare of investors, and can be used as an estimate for investors to invest in, and for academics can be used as a reference in carrying out better research in the future. 


\section{Research Methodology ANd Research Process}

This research methodology used a quantitative approach with the type of causal associative bonding. Causal associative research is defined as research that determines the effect of causality from the independent variable (X), namely firm size is calculated using by Ln total sales, leverage is computed by Debt to Asset Ratio (DAR), Profitability is calculated by Return On Equity (ROE), and dividend policy is calculated by Dividend Payout Ratio (DPR) to the dependent variable (Y), which is the firm value calculated by Price Book Value (PBV).

The kind of data used in this exploration is secondary data acquired from IDX. Then the information be used in this research is the yearlong financial report of food and beverage companies for 2016-2019 which are listed on the IDX. The population in this study are food \& beverage companies listed on the IDX in 2016-2019. The sample of this research used purposive sampling with the sample benchmark is the food and beverage firms that distributed dividends within 4 consecutive years starting from 2016, 2017, 2018, and 2019.

Based on this criteria, the following research samples were obtained:

Table 1. Sample Lists of Consumer Goods Industry Companies, Sub Sector of Food and Beverages

\begin{tabular}{|c|l|c|}
\hline No & \multicolumn{1}{|c|}{ Company Name } & Company Code \\
\hline 1 & PT Indofood CBP Sukses Makmur Tbk. & ICBP \\
\hline 2 & PT Indofood Sukses Makmur Tbk. & INDF \\
\hline 3 & PT Mayora Indah Tbk. & MYOR \\
\hline 4 & PT Multi Bintang Indonesia Tbk. & MLBI \\
\hline 5 & PT Ultra Jaya Milk Industry \& Trading Company Tbk. & ULTJ \\
\hline 6 & PT Nippon Indosari Corporindo Tbk. & ROTI \\
\hline 7 & PT Delta Djakarta Tbk. & DLTA \\
\hline 8 & PT Wilmar Cahaya Indonesia Tbk. & CEKA \\
\hline 9 & PT Sekar Laut Tbk. & SKLT \\
\hline 10 & PT Budi Starch \& Sweetener Tbk. & BUDI \\
\hline
\end{tabular}




\section{LITERATURE REVIEW}

\section{Signalling Theory}

One of the main theories in studying financial management is the signalling theory (Fauziah, 2017). The signal in question is a sign that the company gives to investors. The form of the signal given is in the form of one that can be observed immediately or one that needs to be studied more deeply in order to understand it. This was attempted by the company to share signals with investors in order to find out the development of the enterprise's management in seeing the enterprise's future opportunities to compare quality and inferior companies.

\section{Value Relevance}

Value relevance is an accounting disclosure that has an approximate form related to market value. Each company has an obligation to shareholders or prospective shareholders, one of which is by publishing their financial information in an as is manner according to the condition of the company. Relevance theory proves that data originating from the accounting stage should be used by readers to determine investment decisions. The relationship between financial information and share prices is a classic concept known as value relevance (Alfraih, 2016).

\section{Firm Value}

The Firm value is the market value of a firm that can be used to distribute the maximum welfare to shareholders if the share price of a company increases. Firm value is what investors perceive the company as, which is often related to share prices. This shows that one aspect that is considered by investors in investing is the value of the company that will be the place to invest (Suffah \& Riduwan, 2016). 


\section{Firm Size}

Firm size is a calculation where the size of the firm can be restricted as measured by total assets, total sales, share price and others (Widiastari \& Yasa, 2018). The firm size is a measurement which can be used to categorize the size company with various calculation methods, including ln total assets, ln total sales, and market capitalization. The large company generally has large outstanding shares and is more courageous in adding new shares to meet production and sales activities than a relatively small enterprise.

\section{Leverage}

Leverage is a comparison used to quantify the enterprise's expertise in carrying out all current or future obligations (Sujarweni, 2017). In a sense, leverage is the comparison used to calculate the weight of the loan that must be paid by the company. How actively does the company use existing facilities, facilities that are defined as receivables, capital, or assets. Companies that usually carry out a lot of funding with liability are advised not good because they can reduce gains. Large debts result in less favorable thinking from investors on company value. The high level of leverage can sway the interest of investors in investment conclusions in the company, cause the company may not be able to share large profits with investors.

\section{Profitability}

Profitability is a comparison used to calculate the enterprise's performance in creating gains from its business actions. With the high level of gain a firm, the welfare of the shareholders of one of the company's stakeholders will also increase (Hery, 2017). Companies should optimize the abilities of employees and management in order to achieve predetermined targets so that the firm can get maximum benefits.

\section{Dividend Policy}

Dividend policy is a firm's judgment to dispart operating gains proportionally to investors or to postpone the distribution and include it in retained earnings 
which can later be used for funding in the following year (Defrizal \& Mulyawan, 2015). The company is supposed to pay dividends to investors, which is the duty of the company to give part of the profits to investors. This dividend payment can be used as a form of information to prospective investors before committing to investing.

\section{RESEARCH HYPOTHESIS}

\section{The Effect of Firm Size, Leverage, Profitability, and Dividend Policy on Firm Value}

The company size is reflected in the total assets, total sales, the mean level of sales and the mean total assets of the company. Larger companies can access the capital market in order to obtain funding more easily. Meanwhile, companies that are still recent and little companies will experience many toughs in accessing the capital market. According to Hirdinis (2019), company size has a negative and significant impact to company value.

Leverage is an effort to increase operating income which can also be used as a benchmark in observing manager behavior in earnings management activities. Firm value can also be affected by the leverage size effected of the firm. Leverage has a positive and significant clout on company value (Markonah, 2020).

High profitability illustrates the better the firm's capability to generate gains. The top of firm's gains, the better company is in the eyes of investors. Profitability has a positive and significant clout on company value (Sari \& Sedana, 2020).

The dividend policy set by the firm's management is an alert for investors to assess the condition of the firm. With high dividend distribution to shareholders, it is hoped that the firm's value will also increase. Most investors certainly want a dividend policy that can satisfy them. The effect of dividend policy proxied by DPR and company value proxied by PBV is positive and significant (Rehman, 2016).

Based on the definition over, it can be resumed that the first hypothesis is:

$\mathrm{H}_{1}$ : There is an impact of company size, leverage, profitability, and dividend policy simultaneously on company value. 


\section{The Effect of Firm Size on Firm Value}

The companies are categorized into two types, namely small-scale companies and large-scale companies. The size of the company value will affect the value of the company based on the fact that the bigger a company has a high level of added assets so that it can earn profits which will affect the value of the company. Husna's and Satria's research results (2019) state that company size has a positive effect on firm value, the higher the size of a company, the higher the company value.

Firm size is the variables that are considered in deciding the value of a company. Pursuant to Goka, et. al. (2018) the variable company size has no effect on firm value (PBV) and has a positive relationship with company value (PBV). However, this is not in analogous with study conducted by Hirdinis (2019), where firm size has a negative and significant impact on firm value.

Based on this explanation, it can be formulated for the second hypothesi$s$ as follows:

$\mathrm{H}_{2}$ : Company size has a positive impact on company value.

\section{The Effect of Leverage on Firm Value}

The company can be called unsolvable if the company's total assets are less than the company's total debt. This can make investors more careful to invest in companies that have a large leverage ratio because the leverage ratio can show the level of investment risk. Debt that continues to grow out of control. Study done by Farooq (2016) show that leverage has a negative and significant impact on company value. A high leverage number is not always a low company value, likewise a low leverage number does not always increase firm value. By reason of investors see from sundry sides of financial reports.

The results of study conducted by Markonah (2020), indicate that leverage with the proxy Debt to Equity Ratio (DER) has a positive and significant effect on firm value. Then the leverage which is proxied by the Debt to Assets Ratio (DAR) has a negative impact on company value (Hakim \& Sunardi, 2017).

Based on the definition over, it can be resumed that the third hypothesis is: $\mathrm{H}_{3}$ : Leverage has a negative impact on company value. 


\section{The Effect of Profitability on Firm Value}

Profitability is the company's ability to earn profits within a certain period of time. The principle of profitability assessment is contained in the financial statements that are on the balance sheet and the company's income statement (Sitorus \& Denny, 2017). Theoretically, increasing company profitability will increase firm value. This is due to profitability as a signal for investors to be able to invest in the company. The high profitability of the company encourages investors to invest by making a request to get company stocks. Thus, the stock value will increase due to the great demand for shares. Profitability has a positive and significant impact on company value (Tui, Nurnajamuddin, Sufri \& Nirwana, 2017).

According to Cambarihan and Sucuahi (2016) state that profitability has a positive and significant effect on company value. Then in previous study that discusses the relationship of profitability to company value and is related to this research, including by Paminto, Setyadi and Sinaga (2016), the outcomes of the research show that profitability has a positive impact on company value.

Based on the definition over, it can be concluded that the fourth hypothesis is: $\mathrm{H}_{4}$ : Profitability has a positive impact on company value.

\section{The Effect of Dividend Policy on Firm Value}

Dividend policy is still possible to be one of the important manners for great shareholders to perforate registed firms thru the "tunnel effect". As a result, some companies with poor performance often issue large dividends that can damage the value of the company (Hailin \& Jingxu, 2019). Dividend policy is a judgment if the gains earned by the firm at the final year will be dispart to shareholders in the establish of dividends or will be holded to escalate fund for investment financing in the hereafter. Dividend policy is very important because of the influence of investment, finance and liquidity. To achieve the goal, the company ensures a dividend policy, namely a policy made by the company for the portion of income received as dividends paid, that is, profit that can be guaranteed and as net profit and profit on its shares.

Rehman's research results (2016) argue that dividend policy has a positive and significant impact on company value. Watchfulness by Husna and Satria (2019) shows that dividend policy has no significant clout on firm value. Then 
the results of Hafeez's, Shahbaz's, Iftikhar's and Ali Butt's research (2018) also show that dividend policy has a positive effect on firm value. These results indicate that distributing dividends will increase firm value.

Based on the definition over, it can be resumed that the fifth hypothesis is:

$\mathrm{H}_{5}$ : Dividend policy has a positive effect on firm value.

\section{RESUlt AND CONCLUSIONS}

Multiple linear regression analysis used to see the direction of the relation between the independent variable (X) of firm size (Ln Total Sales), leverage (DAR), profitability (ROE), and dividend policy (DPR) with the dependent variable (Y), firm value ( $\mathrm{PBV}$ ). The outcomes of multiple linear regression tests can be observed as follows:

Table 2. Multiple Linear Regression Test Results

\begin{tabular}{|l|l|c|c|c|c|c|}
\hline \hline \multicolumn{2}{|c|}{ Model } & $\begin{array}{c}\text { Unstandardized } \\
\text { B }\end{array}$ & $\begin{array}{c}\text { Coefficients } \\
\text { Std. Error }\end{array}$ & $\begin{array}{c}\text { Standardized } \\
\text { Coefficients } \\
\text { Beta }\end{array}$ & t & Sig. \\
\hline \hline \multirow{2}{*}{1} & (Constant) & -5.783 & 7.864 & & -0.735 & 0.467 \\
\cline { 2 - 7 } & X1_Size & 0.042 & 0.268 & 0.007 & 0.158 & 0.875 \\
\hline & X2_DAR & 6.446 & 2.650 & 0.120 & 2.432 & 0.020 \\
\hline & X3_ROE & 0.241 & 0.015 & 0.868 & 16.287 & 0.000 \\
\hline
\end{tabular}

${ }^{a}$ Dependent Variable: Y_PBV

S o u r c e : data processing result.

Based on table 2 , the fixed value is -5.783 , the $\beta_{1}$ value is 0.042 ; the value $\beta_{2}$ is 6.446 ; the value $\beta_{3}$ is 0.241 ; and the value $\beta_{4}$ is 0.036 . Then from the test results, a multiple linear equation can be made as follows: 
$Y=-5.783+0.042 X_{1}+6.446 X_{2}+0.241 X_{3}+0.036 X_{4}+e$

Based on the above similarity, it can be construed as follows:

1. The constant number -5.783 shows that if the company size, leverage, profitability, and dividend policy are zero, the company value is -5.783 .

2. The regression coefficient for firm size as measured using by Ln Total Sales is 0.042 indicating that if each increase in firm size is one, it will cause an escalate in firm value of 0.042 .

3. The leverage regression coefficient measured using by Debt to Assets Ratio (DAR) of 6.446 indicates that if each increase in DAR is one, it will cause an escalate in firm value of 6.446 .

4. The profitability regression coefficient measured using by Return On Equity (ROE) of 0.241 indicates that if each increase in ROE is one, it will cause an escalate in firm value of 0.241 .

5. The dividend policy regression coefficient measured using by Dividend Payout Ratio (DPR) of 0.036 indicates that if each increase in the DPR is one, it will cause an escalate in firm value of 0.036 .

\section{Simultaneous Test (F Test)}

Simultaneous testing was achieved to test the regression model from the effect of all independent variables, namely $\mathrm{X}_{1}, \mathrm{X}_{2}, \mathrm{X}_{3}$, and $\mathrm{X}_{4}$ synchronously on the dependent variable $(\mathrm{Y})$.

The criteria for this simultaneous test are as follows:

1. Ho is fulfilled and Ha is rejected if the significance value is greater than 0.05 .

2. Ho is rejected and $\mathrm{Ha}$ is fulfilled if the significance value is smaller than 0.05 .

The simultaneous test that has been carried out can be seen as follows: 
Table 3. Simultaneous Test Result (F Test)

\begin{tabular}{|c|c|c|c|c|c|c|}
\hline \multicolumn{7}{|c|}{ ANOVA $^{a}$} \\
\hline & Model & Sum of Squares & df & Mean Square & $\mathbf{F}$ & Sig. \\
\hline \multirow[t]{3}{*}{1} & Regression & 2668.163 & 4 & 667.041 & 108.677 & $0.000^{\mathrm{b}}$ \\
\hline & Residual & 214.825 & 35 & 6.138 & & \\
\hline & Total & 2882.988 & 39 & & & \\
\hline
\end{tabular}

a Dependent Variable: Y_PBV

b Predictors: (Constant), X4_DPR, X2_DAR, X1_Size, X3_ROE

S o u r c e : data processing result.

Based on the result of the simultaneous test above, it is found that the F number count is equal to 108.677 and the $\mathrm{F}$ significance is 0.000 which means that the significance number is less than 0.05 , this proves that $\mathrm{Ha}_{1}$ is accepted, which means that there is a predispose on company size, leverage, profitability, and dividend policy together (simultaneously) to company value.

\section{Partial Test (T Test)}

Based on the table 2 it can be interpreted as follows:

1. The firm size is obtained by the B coefficient value of 0.042 and the significance value of 0.875 , which is a significance number preponderant than 0.05 . So, it proves that $\mathrm{Ho}_{2}$ is fulfilled and $\mathrm{Ha}_{2}$ is rejected, which means that there is no impact of firm size on firm value partially.

2. Leverage is obtained by the B coefficient value of 6.446 and a significance number of 0.020 , which is a significance number less than 0.05 . So, it proves that $\mathrm{Ho}_{3}$ is rejected and $\mathrm{Ha}_{3}$ is fulfilled, which means that there is a significant and positive relation among leverage and firm value.

3. Profitability obtained by the B coefficient value of 0.241 and a significance number of 0.000 , which is a significance number less than 0.05 . So, it proves that $\mathrm{Ho}_{4}$ is rejected and $\mathrm{Ha}_{4}$ is fulfilled, which means that there is a positive and significant relation among profitability and firm value.

4. Dividend policy obtained by the B coefficient value of 0.036 and a significance number of 0.025 , which is a significance number less than 0.05 . So, 
it proves that $\mathrm{Ho}_{5}$ is rejected and $\mathrm{Ha}_{5}$ is fulfilled, which means that there is a significant and positive relation among dividend policy and firm value.

\section{Determination Coefficient Test (Adjusted R2 Test)}

The calculation of the adjusted $\mathrm{R}^{2}$ with a range of values from 0 to 1 . If the amount of adjusted $\mathrm{R}^{2}$ continues to be large, the results of the regression can reveal if the independent variable can explain the totality of its effect on the dependent variable. If adjusted $R^{2}=0$, then the independent variable cannot explain if the estimated relation to the dependent variable is correct. And if the test results prove $R^{2}=1$, then the independent variable can define the approximate relation to the dependent variable. The results of the determination coefficient test are as follows:

Table 4. Determination Coefficient Test Result

\begin{tabular}{|c|c|c|c|c|}
\hline \hline \multicolumn{5}{|c|}{ Model Summary } \\
\hline \hline Model & R & R Square & $\begin{array}{c}\text { Adjusted R } \\
\text { Square }\end{array}$ & $\begin{array}{c}\text { Std. Error } \\
\text { of the Estimate }\end{array}$ \\
\hline \hline 1 & $0.962^{\mathrm{a}}$ & 0.925 & 0.917 & 2.47747 \\
\hline \hline
\end{tabular}

a Predictors: (Constant), X4_DPR, X2_DAR, X1_Size, X3_ROE

${ }^{\mathrm{b}}$ Dependent Variable: Y_PBV

S o u r c e : data processing result.

The result from the coefficient determination test produces an Adjusted $\mathrm{R}^{2}$ number of 0.917 which indicates that $91.7 \%$ of the dependent variable is the firm value which is affected by the independent variables, namely firm size, leverage, profitability, and dividend policy. Then the over $8.3 \%$ is affected by various disparate factors outside the variables used in this research.

\section{ANALYSIS RESULT INTERPRETATION}

The results of $\mathrm{F}$ test, it proves that company size, leverage, profitability, and dividend policy simultanously have an impact on company value. This can be ob- 
served by looking at the results of a significance value of $0.000<0.05, \mathrm{Ha}_{1}$ is accepted. The results of the $\mathrm{F}$ test are also supported by the coefficient of determination which shows that the independent variables, namely firm size, leverage, profitability, and dividend policy have an effect of $91.7 \%$ on company value.

The outcomes of $t$ test from firm size show the B coefficient of 0.042 with a significance level greater than the standard significance level of $0.875>0.05$. The firm size as calculated by Ln Total Sales hasn't effect on the value of food \& beverage companies on IDX. Firm size can not strengthen or weaken firm value because it is likely that the evaluation of firm size doesn't affect to firm value even though sales capacity is increasing or decreasing.

The outcomes of $t$ test from leverage obtained the B coefficient of 6.446 with a significance level lesser than the standard significance level of $0.020<0.05$. This means, leverage as calculated by Debt to Assets Ratio (DAR) has a significant and positive impact on the firm value of food \& beverage companies on IDX. Leverage, which is calculated by Debt to Asset Ratio (DAR) is indicated to have a positive impact on company value. So, if leverage increases, it is followed by an increase in firm value and vice versa. The investors want to think about decided to give financiers in the company that has a large leverage ratio. The increase in leverage is considered as an assessment if the company has the size of the company's assets which in slue can affect the increase in company productivity.

The results of $t$ test from profitability obtained the B coefficient of 0.241 with a significance level smaller than the standard significance level of 0.000 $<0.05$. This means if profitability is measured using by Return On Equity (ROE) there is an important and positive influence on the firm value of food \& beverage companies on IDX. The Large profitability can provide positive signals to investors when the company is in a profitable circumstance. A company that is able to increase its profitability every year will generate large profits which also reflects that if the company's capabilities are good.

The results of $t$ test from dividend policy show the B coefficient of 0.036 with a significance level lesser than the standard significance level of 0.025 $<0.05$. This means that dividend policy as calculated by using the Dividend Payout Ratio (DPR) has a significant and positive impact on the company value of food and beverage companies on IDX. Firms that pay large of dividends will indirectly affect the charge of large shares and affect the value of the company. Dividends paid must be in balance with the needs of the company or company shareholders. A good corporate dividend policy is a policy that creates a bal- 
ance between the current dividend distribution and future dividend developments that can optimize stock prices. An increase in dividend payments can be a positive alert for investors because they consider the company to have good and profitable prospects in the future tense.

\section{ConCLusion}

Based on the analysis and review results, it shows that company size, leverage, profitability, and dividend policy simultaneously affect to company value. Firm size has no impact on company value. Leverage has a positive impact on company value. Profitability has a positive impact on company value. Dividend policy has a positive impact on company value. The coefficient of determination of 0.917 proves that firm size, leverage, profitability, and dividend policy have an effect of $91.7 \%$ on firm value.

\section{REFERENCES}

Alfraih, M.M. (2016). Have Financial Statements Lost Their Relevance? Empirical Evidence From The Frontier Market Of Kuwait. Journal of Advances in Management Research, 13(2), 225-239. http://dx.doi.org/10.1108/JAMR-06-2015-0043.

Ayem, S., \& Nugroho, R. (2016). The Effect of Profitability, Capital Structure, Dividend Policy, and Investment Decisions on Firm Value (Case Study of Manufacturing Companies Going Public on the Indonesia Stock Exchange) Period 2010-2014. Jurnal Akuntansi, 4(1), 31-40. http://dx.doi.org/10.24964/ja.v4i1.125.

Cambarihan, J.M., \& Sucuahi, W. (2016). Influence of Profitability to the Firm Value of Diversified Companies in the Philippines. Accounting and Finance Research, 5(2), 149-153. http://dx.doi.org/10.5430/afr.v5n2p149.

Defrizal, D., \& Mulyawan, M. (2015). Analysis of the Effect of Financial Ratios on Stock Returns (Study on Manufacturing Sector Shares Listed on the Indonesia Stock Exchange 2008-2012). Jurnal Manajemen Dan Bisnis, 6(1), 22-40. http://dx.doi. org/10.36448/jmb.v6i1.829.

Ernawati, D., \& Widyawati, D. (2015). Effect of profitability, leverage and firm size on firm value. Jurnal Ilmu dan Riset Akuntansi, 4(4), 1-17.

Farooq, M.A., \& Masood, A. (2016). Impact of Financial Leverage on Value of Firms: Evidence from Cement Sector of Pakistan. Research Journal of Finance and Accounting, $7(9), 73-77$.

Fauziah, F. (2017). Bank Soundness, Dividend Policy and Firm Value: Theory and Empirical Study. Samarinda: Pustaka Horizon.

Hafeez, M., Shahbaz, S., Iftikhar, I., \& Ali Butt, H. (2018). Impact of Dividend Policy on Firm Performance : Evidence from the Manufacturing firms in Pakistan. Internation- 
al Journal of Advance Study and Research Work, 1(4), 1-5. http://dx.doi.org/10.5281/ zenodo.1312180.

Hailin, Q., \& Jingxu, Z. (2019). Can Mandatory Dividend Policy Reduce the Agency Cost of Listed Companies? Model Analysis and Empirical Test in China. Copernican Journal of Finance \& Accounting, 8(1), 59-101. http://dx.doi.org/10.12775/CJFA.2019.003.

Hakim, L., \& Sunardi, N. (2017). Determinant Of Leverage and It's Implication On Company Value Of Real Estate and Property Sector Listing In IDX Period Of 2011-2015. Man in India, 97(24), 131-148.

Harmono, H. (2014). Financial Management Based on the Balanced Scorecard Theory, Case and Business Research Approaches. Jakarta: PT Bumi Aksara.

Hasibuan, M.S.P (2017). Human Resource Management. Jakarta: Bumi Aksara.

Hery (2017). Accounting Theory Concepts and Analysis Approach. Jakarta: PT Grasindo.

Hirdinis, M. (2019). Capital Structure and Firm Size on Firm Value Moderated by Profitability. International Journal of Economics and Business Administration, 7(1), 174-191.

Husna, A., \& Satria, I. (2019). Effects of Return on Asset, Debt to Asset Ratio, Current Ratio, Firm Size, and Dividend Payout Ratio on Firm Value. International Journal of Economics and Financial Issues, 9(5), 50-54, http://dx.doi.org/10.32479/ijefi.8595.

Indriyani, E. (2017). The Effect of Firm Size and Profitability on Firm Value. Akuntabilitas: JurnalIlmu Akuntansi, 10(2), 333-348. http://dx.doi.org/10.15408/akt. v10i2.4649.

Mayliza, R., \& Sari, L.F. (2018). Banking Profitability Viewed from the Aspects of Third Party Funds, Capital Adequacy and Credit Risk. Pundi Journal, 2(2), 199-210. http:// dx.doi.org/10.31575/jp.v2i2.85.

Markonah, A.S. (2020). Effect Of Profitability, Leverage, And Liquidity To The Firm Value. Dinasti International Journal of Economics, Finance, and Accounting, 1(1), 83-94.

Novari, P., \& Lestari, P. (2016). The Effect of Company Size, Leverage, and Profitability on Firm Value in the Property and Real Estate Sector. E-Jurnal Manajemen Unud, 5(9), 5671-5694.

Paminto, A., Setyadi, D., \& Sinaga, J. (2016). The Effect of Capital Structure, Firm Growth and Dividend Policy on Profitability and Firm Value of the Oil Palm Plantation Companies in Indonesia. European Journal of Business and Management, 8(33), 123-134.

Pratama, I., \& Wiksuana, I. (2016). The Effect of Firm Size and Leverage on Firm Value with Profitability as a Mediation Variable. E-Jurnal Manajemen, 5(2), 1338-1367.

Rehman, O.U. (2016). Impact of Capital Structure and Dividend Policy on Firm Value. Journal of Poverty, Investment, and Development, 21, 40-57.

Sari, I.A.G.D.M., \& Sedana, I.B.P. (2020). Profitability and Liquidity on Firm Value and Capital Structure as Intervening Variable. International Research Journal of Management, IT \& Social Sciences, 7(1), 116-127. http://dx.doi.org/10.21744/irjmis. v7n1.828.

Sitorus, T., \& Denny. (2017). The influence of asset and profitability toward share value: Mediation Effect Of Liquid Asset. Copernican Journal of Finance \& Accounting, 6(4), 85-103. http://dx.doi.org/10.12775/CJFA.2017.024. 
Suffah, R., \& Riduwan, A. (2016). Effect of Profitability, Leverage, Company Size and Dividend Policy on Firm Value. Science and Journal of Accounting Research, 5(2), 1-17.

Sujarweni, V.W. (2017). Analysis of Financial Statements Theory, Applications \& Research Results. Yogyakarta: Pustaka Baru Press.

Suwardika, I., \& Mustanda, I. (2017). The Effect of Leverage, Company Size, Company Growth, and Profitability on Firm Value in Property Companies. E-Jurnal Manajemen, 6(3), 1248-1277.

Tui, S., Nurnajamuddin, M., Sufri, M., \& Nirwana, A. (2017). Determinants of Profitability and Firm Value: Evidence from Indonesian Banks. International Journal of Management \& Social Sciences, 7(1), 84-95. http://dx.doi.org/10.21013/jmss.v7.n1.p10.

Widiastari, P.A., \& Yasa, G.W. (2018). Effect of Profitability, Free Cash Flow, and Company Size on Firm Value. E-Jurnal Akuntansi, 23(2), 957-981. http://dx.doi.org/10.24843/ eja.2018.v23.i02.p06. 